\title{
SCHUR-CONVEXITY OF ČEBIŠEV FUNCTIONAL
}

\author{
V. ČULJAK AND J. PEČARIĆ
}

Abstract. In this paper the Čebišev functional $T(f, g ; a, b)$ is regarded as a function of two variables

$$
T(f, g ; x, y)=\frac{1}{y-x} \int_{x}^{y} f(t) g(t) d t-\left(\frac{1}{y-x} \int_{x}^{y} f(t) d t\right)\left(\frac{1}{y-x} \int_{x}^{y} g(t) d t\right),(x, y) \in[a, b] \times[a, b]
$$

The property of Schur-covexity (Schur-concavity) of this function is considered. Some applications for the means are pointed out.

Mathematics subject classification (2010): Primary 26D15, Secondary 26D99.

Keywords and phrases: Convex functions, Schur-convex function, Čebišev functional, Gruss inequality, integral means.

\section{REFERENCES}

[1] N. Elezović AND J. PeČARIĆ, A Note on Schur-convrx functions, Rocky Mountain J. of Mathematics, 30, 3 (2000), 853-856.

[2] Huan-NAn Shi ANd Jian Zhang, Schur-convexity and Schur-geometric convexity of Čebišev functional, RGMIA, 30, 3 (2000), 853-856.

[3] A.W.MARShall and I. Olkin, Inequalities: Theory of Majorization and Its Applications, Academic Press, New York, 1979.

[4] J. E. PeČArić, F. Proschan, And Y. L.Tong, Convex functions, partial orderings, and statistical applications, Academic Press Inc, 1992. 